\title{
Diferenças entre homens e mulheres traduzidas em desi- gualdades nas relações de gênero
}

\section{Differences Between Men and Women Expressed in Inequalities in Gender Relations}

Esta temática, oportunamente retomada nesta edição, recoloca mediante pesquisas e reflexões analíticas a relevância deste constante movimento de retomar, observar, repensar como e por meio de quais especificidades as desigualdades se instituem nas relações sociais e, ideologicamente, tendem a se apresentar como se fossem naturais.

Não se trata de uma nova questão, mas de uma problemática que se recria desde os primórdios da história, assumindo novas dimensões e significados a partir do século 19. A partir deste período, novas classes sociais entram em cena - burguesia e proletariado. No entanto, a análise sociológica que somente as consideram é insuficiente para a compreensão das desigualdades sociais observadas na sociedade moderna; torna-se necessário indagar além, considerar como, no interior das mesmas, outras relações sociais expressam e intensificam diferenças, hierarquias, desigualdades. As relações de gênero ou relações sociais de sexo constituem categorias fundamentais para compreender sociedade ampliando o debate de classes.

Os teóricos fundadores do campo das ciências sociais consideraram, já nas suas análises pioneiras sobre as relações entre as novas classes emergentes, a relevância da participação da mulher para tornar mais compreensível seus argumentos sobre sociedade. Assim, reafirmaram o ponto de vista que pretenderam desenvolver, enquanto representantes que foram de um momento histórico - expansão do capitalismo nascente - e, de visões de mundo diferenciadas para compreendê-lo.

Para Marx (1818-1883), a singularidade do trabalho no capitalismo está na produção do valor, na produção de mercadorias, constituindo a base das relações sociais de classe, de exploração. Em várias passagens de sua obra ele se refere à exploração do trabalho de mulheres (e crianças), enfatizando a dupla dimensão ainda presente no debate atual sobre o trabalho, no contexto da mundialização. Refiro-me à intensificação do trabalho e às condições precárias vivenciadas nas manufaturas de Birmingham (entre outros exemplos), nas quais trabalhavam, de acordo com o autor,

\begin{abstract}
30.000 crianças e jovens, além de 10.000 mulheres. Aí são empregados em atividades insalubres, nas fundições de cobre, na fabricação de botões, nas oficinas de esmaltar, de galvanizar e de laquear. [...] Um dos trabalhos mais humilhantes, mais sujos, e mais mal pagos, em que se empregam de preferência meninas e mulheres, é o de classificar trapos. [...] As classificadoras de trapo servem para transmitir varíola e outras doenças contagiosas das quais são as primeiras vítimas (MARX, 1980, p. 530-531).
\end{abstract}

Inscrito no processo de unificação política da Alemanha, sob hegemonia da Prússia, Max Weber (18641920) foi testemunha da repressão violenta dos trabalhadores por parte do aparelho militar e burocrático do Estado, além de vivenciar o intenso processo de racionalização do capitalismo. As formas de dominação consideradas legítimas foram centrais no desenvolvimento da sociologia nomeada compreensiva, na qual o sentido da ação social foi questionado, por meio da metodologia "tipo ideal". É assim que Weber compreendeu o discurso de Benjamin Franklin, por meio dele analisa a constituição de um novo ethos a organizar a racionalização da sociedade capitalista ocidental constituindo "o espírito do capitalismo", no qual o trabalho é compreendido como vocação, um dever utilitário que possibilita a superação do tradicionalismo.

A "seleção dos mais aptos", conforme analisa o autor, impede a permanência de valores tradicionalistas, capazes de impedir a concretização da "fome do ouro" (auri sacra fames), sobretudo nos processos produtivos nos quais a mecanização libertou a produção das barreiras do trabalho humano e o recrutamento de trabalhadores se desloca da coerção à remuneração. Entre outros exemplos da tensão entre tradicionalismo e o capitalismo racional, Weber analisa os empecilhos que as jovens operárias alemãs construíam para a maximização da produtividade no trabalho, com exceção das mulheres casadas.

Uma imagem retrógrada da forma tradicional do trabalho é atualmente apresentada muitas vezes por operá- 
rias, especialmente pelas que não são casadas. [...] O contrário se dá geralmente e este não é um ponto insignificante de acordo com a nossa visão, apenas com moças com uma formação especificamente religiosa, em especial a pietista. Ouve-se frequentemente, e confirma-o a investigação estatística, que de longe, as melhores oportunidades de uma educação econômica são inegavelmente encontradas neste grupo. A capacidade de concentração mental, tanto quanto o sentimento de obrigação absolutamente essencial para com o próprio trabalho, estão aqui combinados com uma economia estrita que calcula a possibilidade de altos vencimentos, um autocontrole e uma frugalidade que enormemente aumentam a capacidade de produção (WEBER, 1980, p. 193).

As principais categorias que possibilitaram a elaboração de uma metodologia positiva para a análise da sociedade moderna, compreendida como um complexo integrado de fatos sociais encontra em Émile Durkheim (1858-1917), uma contribuição relevante e ideológica. Para o autor, a divisão do trabalho em uma sociedade complexa, é fonte de solidariedade orgânica do corpo social, no qual a cabeça é constituída por uma elite e os trabalhadores são seus membros. $\mathrm{O}$ ordenamento moral expresso por meio da consciência social evitaria expressões de anomia, tais como expressas nos conflitos sociais. A família é considerada pelo autor como um dos exemplos significativos da ordem moral, capaz, pelo processo de socialização, de preparar novas gerações para a ordem considerada necessária para o progresso. Nela, a mulher desempenha papel fundamental, na constituição "da moral doméstica".

Durkheim não compreende relevante considerar as relações sociais de classe ou de sexo como diferenciações significativas na análise sociológica, o que o faz criticar a autora Marianne Weber, socióloga e feminista, casada com Max Weber. A resenha de um dos seus livros foi elaborada e publicada por Durkheim, em 1907 - L’Année Sociologique, v. XI, 1906-1909 - e, nela, o autor critica "o simplismo da argumentação de Madame Weber, ao desenvolver sua tese de que a família patriarcal determinou uma completa subserviência da mulher" (RODRIGUES, 1984, p. 644-649). Para Durkheim, a análise de Marianne Weber não compreendeu a importância da solidariedade na divisão do trabalho social, considerada, citando Augusto Comte, como "a condição essencial da vida social". Para Comte, que tanto influenciou Durkheim, “[...] os proletários reconhecerão, sob o impulso feminino, as vantagens da submissão e de uma digna irresponsabilidade [...] graças à doutrina positivista que há de preparar os proletários para respeitarem, e mesmo reforçarem as leis naturais da concentração do poder e da riqueza"(COMTE, 1973 apud LÖWY, 2000, p. 24).
As visões sociais de mundo diferenciadas, que informam as análises sociológicas fundadoras, encontram na categoria trabalho uma das pedras angulares para a reflexão. Nela, o trabalho da mulher é sempre tomado como um paroxismo que possibilitou aos autores colorir, com cores ainda mais fortes, o que observavam na sociedade moderna emergente: exploração, dominação, coesão social.

Os artigos deste número dessa revista atualizam o debate presente na articulação entre classes sociais e relações de gênero. Neles, uma permanência as mulheres continuam a revelar, mais intensamente, as formas sociais que revestem as hierarquias e desigualdades no presente, quer seja no Brasil, na Argentina, na Colômbia ou em Angola; quer seja por meio da análise das políticas públicas ou da participação em contextos democráticos. Ou ainda, nos espaços de produção (empregadas domésticas, cuidadoras, jornalistas ou gestoras em multinacionais) ou nas famílias, espaços de reprodução social. Assim, as análises informam que o expressivo crescimento da participação da mulher no mercado de trabalho nos países industrializados, no contexto da mundialização, não significa a superação das desigualdades entre homens e mulheres, nem dos discursos positivistas que as justificam, por meio de novas palavras de ordem, tais como equidade. Portanto, a análise das relações sociais de classe e gênero continuam a desafiar o campo do conhecimento das ciências sociais.

\section{Referências}

LOWY, M. As aventuras de Karl Marx contra o Barão de Münchhausen. São Paulo: Cortez, 2000.

MARX, K. O capital. Crítica da economia política. Rio de Janeiro: Civilização Brasileira, 1980.

RODRIGUES, J. A. (Org.). Émile Durkheim: sociologia. Tradução de Laura Natal Rodrigues. São Paulo: Ática, 1984.

WEBER, K. Aética protestante e o espírito do capitalismo. In: WEBER, M. 1864-1920. Textos selecionados. Seleção e tradução de Mauricio Tragtenberg. São Paulo: Abril Cultural, 1980. (Coleção Os Pensadores).

\section{Liliana Rolfsen Petrilli Segnini}

lilianaseg@uol.com.br

Doutorado em Ciências Sociais pela PUC-SP

Pós-Doutorado, Université de Paris X, Nanterre e Genre et Rapports Sociaux,IRESCO-CNRS

Professora Titular de Sociologia do Trabalho - FE e IFHC/Unicamp 